\title{
USE OF SOLID RECOVERED FUEL (SRF) IN CEMENT INDUSTRY - ECONOMIC AND ENVIRONMENTAL IMPLICATIONS
}

\author{
Nikola Dondur* \\ University of Belgrade, Faculty of Mechanical Engineering, Belgrade, Serbia \\ Aleksandar Jovović \\ University of Belgrade, Faculty of Mechanical Engineering, Belgrade, Serbia \\ Vesna Spasojević-Brkić \\ University of Belgrade, Faculty of Mechanical Engineering, Belgrade, Serbia \\ Dejan Radić \\ University of Belgrade, Faculty of Mechanical Engineering, Belgrade, Serbia \\ Marko Obradović \\ University of Belgrade, Faculty of Mechanical Engineering, Belgrade, Serbia \\ Dušan Todorović \\ University of Belgrade, Faculty of Mechanical Engineering, Belgrade, Serbia \\ Sonja Josipović \\ University of Belgrade, Faculty of Mechanical Engineering, Belgrade, Serbia \\ Miroslav Stanojević \\ University of Belgrade, Faculty of Mechanical Engineering, Belgrade, Serbia
}

In the paper we have analysed whether and to what extent co-incineration of secondary fuels in cement manufacturing is cost-effective. Techno-economic assessment shows that combined combustion of solid recovered fuel and traditional fossil fuel (petroleum coke) is economically viable to the extent of 20:80 per cent. The paper also concluded that the impact of the plants on the quality of air would be negligible.

Key words: Solid recovered fuel, Environment, Economic, Risk

\section{INTRODUCTION}

In order to reduce energy dependence on conventional fossil fuels and negative effects on the environment, cement industry is increasingly turning toward alternative fuels. Cement manufacturing is highly energy-intensive, with energy resources typically accounting for $30-40 \%$ of the product price. Traditionally, the primary fuel is coal, though other fuels such as petroleum coke, natural gas and oil are also used. Besides these fuels, various types of wastes can also be used as fuels. Solid Recovered Fuel (SRF) is mechanically fragmented solid secondary raw materials, i.e. waste having the use value for energy generation (not eligible for recycling) and is qualified, by its nature, as non-hazardous waste. Use of waste materials as alternative fuels in cement industry started in the 1970 s and since then the number of cement plants worldwide using alter- native fuels and raw materials has steadily increased. In order to lower the costs of energy resources, cement plants in the European Union follow a long-established practice that the primary fuel (commonly coal) is replaced by secondary fuels. The most frequent secondary fuels include waste or recycled materials which have high heating value and which are convenient for burning in cement kilns. High temperatures in a cement kiln destroy these materials in the environment-friendly and energy-efficient manner. A large number of countries are replacing the primary fuels with secondary fuels even up to $50 \%$ of the specific heat needed for the clinker making process. Use of secondary fuels primarily depends on the availability of that type of fuel. Therefore, it is necessary to conduct a technoeconomic analysis that will show whether and to what extent co-incineration of secondary fuels in cement manufacturing is cost-effective [05]. 


\section{TECHNOLOGICAL PROCESS}

The cement manufacturing process includes the following technological steps: exploitation and preparation of raw materials (limestone, marl and clay); grinding, transportation and storage of raw materials; production and storage of raw meal; fuel storage, transportation and preparation; clinker production, transportation and storage; cement production, transportation and storage; cement packing and palletising, shipping. Raw meal is produced by grinding raw materials in the raw material grinding mill. The components include: a mix of marl and limestone, pure limestone, clay, pyrite burning and bauxite. The core and dominant component is a mix of limestone and marl. Other components are used for correcting the contents of the necessary oxides in the raw meal. Function of the raw mill is to dry and grind the raw mix. The raw materials are dried in the mill drying chamber where these materials are also partly crushed by rotation movement causing friction. Drying is done by bringing hot gases from the rotary kiln or from the rotary kiln which is used when the rotary kiln is not working or not producing sufficient quantity of hot gases. In the mill raw materials are crushed by means of the diameter $20-90 \mathrm{~mm}$ grinding balls until the desired fineness is achieved. The ground raw materials are sent by air flow through the pipeline into the separator - grit separator. In the separator itself bigger particles of the raw meal are separated. Thus separated bigger particles go, by free fall, to the air slide which returns them to the mill for regrinding. Fine particles of the raw meal go through the pipeline to two cyclones. From the cyclone the ground materials are pneumatically transported to the silos for homogenization while one part of the air flow is injected through an appropriate pipe into the cooling tower and further to the electrostatic precipitator and the other part of the air flow is reversed, through a pipeline, to recirculate through the mill, pipeline, separator and cyclones. Since the temperature of gases entering the electrostatic precipitator is high, the plant for cooling of gases is used - cooling tower. The cooling tower also operates as a cyclone and therefore part of raw meal falls on the transport system through which it is brought back into the process. Smaller particles of the raw meal are drawn from the cooling tower, by ventilator, into the electrostatic precipitator. After separation of the raw meal particles, these par- ticles are taken from the electrodes (by means of the shakers) through the screw conveyor to the T-section and further to the airlift. The raw meal is then transported pneumatically from the airlift through the pipeline to the homogenization silos. In the homogenization silos raw meal is finally mixed by compressed air and chemical components are blended. Homogenized raw meal is brought through the silos discharge device into the raw meal silos into which the air is injected so that the raw meal stays loose. From these silos, through the silos discharge devices, the raw meal is transported further into the rotary kiln.

Technological basis of the cement clinker manufacturing process is the rotary kiln with fourstage cyclone heat exchanger (pre-heater) with satellite cooler and burner, using the dry process technology. (Figure 1.)

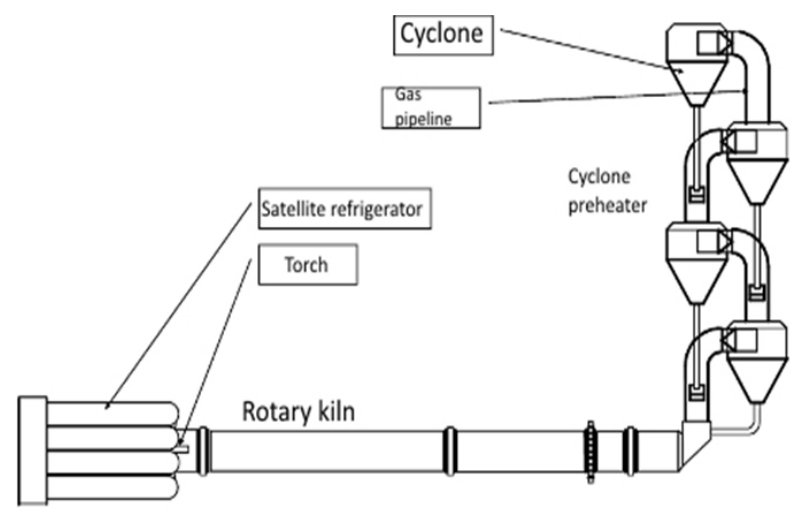

Fuel oil, petroleum coke or coal is used as fuel for the rotary kiln. However, to be used as fuels for the rotary kiln, these fuels need to be prepared before use and therefore the new solid fuel drying and grinding plant was designed. Clinker, as a main semi-manufactured product in the cement manufacturing process, is made by burning raw meal in the rotary kiln. The main process conditions in the rotary kiln are as follows: raw mix is kept for long time, oxygen-rich environment $\left(\mathrm{O}_{2}\right)$, temperature of the raw mix is up to $1500{ }^{\circ} \mathrm{C}$ and temperature of the gases up to $2000^{\circ} \mathrm{C}$, temperature of the flame at the top of the burner is over $2000^{\circ} \mathrm{C}$, which causes intensive degradation of lime $\left(\mathrm{CaCO}_{3}\right)$ to calcium oxide, known as quicklime or burnt lime $(\mathrm{CaO})$ and carbon dioxide $\mathrm{CO} 2$ at temperatures below 800 ${ }^{\circ} \mathrm{C}$. The main component in the cement making process is clinker, with the use of the following additives: gypsum (necessary to control the setting time of the cement), slag, fly ash and lime. However, as the clinker is the basis for manu- 
facturing cement, cement quality depends on the clinker quality, percentage and fineness of grind.

\section{Used energy and possibility of using SRF}

In the cement plant in which economic justification of the use of the solid recovered fuel produced from waste (SRF), petroleum coke, coal and fuel oil are used as main fuels for the rotary kiln. In 2010 the share of coal was $2.5 \%$ and of petroleum coke $95.7 \%$, whereas in 2011 the share of coal was $68.6 \%$ and petroleum coke $29.5 \%$ respectively. In the 2009-2011 period consumption of petroleum coke ranged from 41389 to 11065 tons. Consumption of coal in 2011 was 34725 tons. According to the Project, it is planned to use solid recovered fuel which can be found on the market and which meets appropriate quality standards [01] The planned maximum volume of the use of solid recovered fuel is 25,000 tons per year (capacity of 48 tons per day, that is, 2 tons per hour, with the maximum level of substitution of the main fossil fuels of $24 \%$ ).

$\mathrm{SRF}$ is most frequently produced in the plants (in the vicinity of municipal waste landfills) where after separating the recyclable fractions of waste, the remaining residue is fragmented, dried, stabilised and packed [06]. SRF consists of fuel segments of waste: paper, fabric, light fractions of artificial materials, wood, rope, yarns, etc.

\section{IMPACT ON THE ENVIRONMENT BY USING SRF}

In the observed Cement Plant, pollutants discharged into the air, primarily solid particles generated in the course of the manufacturing process (crushing and grinding of the raw mix, technological process in the rotary kiln, transport, storage and grinding of the cement clinker, cement packaging and transport, storage and grinding of the solid fuels, etc.) as well as gas components (from fuel burned and technological gases) are generated.

Experiences from other (similar) cement plants where solid recovered fuel is already used as alternative fuel show no increase in the gas and solid particle emissions above Emission Limit Value (ELV) nor threat that transport and/or burning of this material will deteriorate the quality of air in the immediate environment and beyond. Manipulating the SRF in the warehouse, dosage and transport will not cause any deterioration of the air quality in the wider area of the cement plant complex. As the fuel combustion gas products which are dosed on the side of the main burner spend considerable time in the rotary kiln, there is no possibility that some component (particularly not an organic component) or fuel combustion product is not fully decomposed and converted into the simplest oxides. To that end, the calculation of the SRF co-combustion in the cement kiln was made, as follows:

- The SRF flow of $3,000 \mathrm{~kg} / \mathrm{h}$ is adopted,

- Operation of the kiln with fossil fuel as well as with the mix fossil fuel +SRF (co-combustion)

- For the SRF which meets requirements of the technical standards, as well as for the operation of the kiln with and without SRF, the emission factors are adopted, based on the EU, EPA, Solid Recovered Fuels, Contribution to BREF "Waste Treatment", European Recovered Fuel Organisation, Thomas Glorius, Joop van Tubergen, Institute and Chair of Processing and Recycling of Solid Waste, RWTH Aachen, EUROPEAN COMMISSION - DIRECTORATE GENERAL ENVIRONMENT REFUSE DERIVED FUEL, CURRENT PRACTICE AND PERSPECTIVES (B4-3040/2000/306517/MAR/E3) FINAL REPORT.

Flue gas flows from the process of co-incineration of SRF in the cement kiln, obtained in the calculation, are shown in Table 1, whereas Table 2 shows data on the rotary kiln processes.

Table 1: Flue gases flows in cement kiln

\begin{tabular}{|c|c|c|}
\hline Flue gases & Values & Units \\
\hline Flows on $10 \% \mathrm{O}_{2}$ & 145000 & $\mathrm{Nm}^{3} / \mathrm{h}$ \\
\hline Total flows & 145000 & $\mathrm{Nm}^{3} / \mathrm{h}$ \\
\hline SRF flue gases flows & 25500 & $\mathrm{Nm}^{3} / \mathrm{h}$ \\
\hline $\begin{array}{c}\text { Flue gases flows from } \\
\text { other fuels }\end{array}$ & 119500 & $\mathrm{Nm}^{3} / \mathrm{h}$ \\
\hline
\end{tabular}

Table 2: Flue gases flows in rotary kiln

\begin{tabular}{|c|c|c|}
\hline Flows & Values & Units \\
\hline SRF & 3000 & $\mathrm{~kg} / \mathrm{h}$ \\
\hline Clinker & 66660 & $\mathrm{~kg} / \mathrm{h}$ \\
\hline SRF/Clinker & 0,05 & $\mathrm{~kg} \mathrm{SRF} / \mathrm{kg}$ klink. \\
\hline $\begin{array}{c}\text { Petroleum } \\
\text { coke (wet) }\end{array}$ & 7044 & $\mathrm{~kg} / \mathrm{h}$ \\
\hline $\begin{array}{c}\text { Petroleum } \\
\text { coke (dry) }\end{array}$ & 6725 & $\mathrm{~kg} / \mathrm{h}$ \\
\hline
\end{tabular}


Table 3: Shows values of flue gases flows components obtained by calculation

\begin{tabular}{|c|c|c|c|c|c|}
\hline Components & $\begin{array}{l}\text { Concentration of } \\
\text { SRF in } 10 \% \mathrm{O}_{2}, \\
\text { calculated } \\
{\left[\mathrm{mg} / \mathrm{Nm}^{3}\right]}\end{array}$ & $\begin{array}{c}\text { Concentration } \\
\text { without SRF in } \\
10 \% \mathrm{O}_{2}, \\
\text { measured } \\
{\left[\mathrm{mg} / \mathrm{Nm}^{3}\right]^{1}}\end{array}$ & $\begin{array}{c}\text { Total concentration, } \\
{\left[\mathrm{mg}^{\left.-\mathrm{Nm}^{3}\right]}\right.}\end{array}$ & $\begin{array}{l}\text { Flow } \\
{[\mathrm{kg} / \mathrm{h}]}\end{array}$ & $\begin{array}{c}\text { GVE } \\
{\left[\mathrm{mg} / \mathrm{Nm}^{3}\right]}\end{array}$ \\
\hline $\mathrm{PM}$ & 14 & 1,23 & 3,476 & 0,5039 & 30 \\
\hline $\mathrm{NOx}$ & 262 & 744,66 & 659,78 & 95,668 & 800 \\
\hline SOx & 4 & 0 & 0,7034 & 0,102 & 50 \\
\hline $\mathrm{CO}$ & 53 & 75,33 & 71,403 & 10,353 & 500 \\
\hline TOC & 10 & 6 & 6,703 & 0,972 & 10 \\
\hline PCDD & 0,000000068 & $3,5 \cdot 10-9$ & $1,484 \cdot 10-8$ & $2,152 \cdot 10-9$ & 0,0000001 \\
\hline
\end{tabular}

1 - existing emissions

In order to assess the impact of the use of SRF on the air quality, a model of dispersion of pollutants $\left(\mathrm{NO}_{2}, \mathrm{SO}_{2}\right.$, dust, $\left.\mathrm{CO}\right)$ from the main emitters (stack of the kiln, raw mill, cement mill and solid fuel mill).Within the assessment of the impact of the cement plant on the environment (Environmental Impact Assessment), the standard model EPA (U.S. Environmental Protection Agency) AERMOD was used. Models for the needs of this study covered a modelling domain of $20 \times 20 \mathrm{~km}$ with the cement plant in the centre. By applying the AERMOD, a 3D model of the cement plant was made (Figure 2.), covering only those facilities which are relevant for dispersion modelling..

Figure 3. shows the results of dispersion modelling of total dust from three main cement plant emitters with the use of SRF. The maximum obtained value for the averaging over one-year period is $0.13403 \mu \mathrm{g} / \mathrm{m3}$, and this value is recorded on the slopes of the hill, located approx. $1 \mathrm{~km}$ south of the Cement Plant. Considering the maximum allowable value for this pollutant component of $70 \mu \mathrm{g} / \mathrm{m} 3$. [02], it can be concluded that, considering this pollutant, the impact of the plants on the quality of air would be negligible.

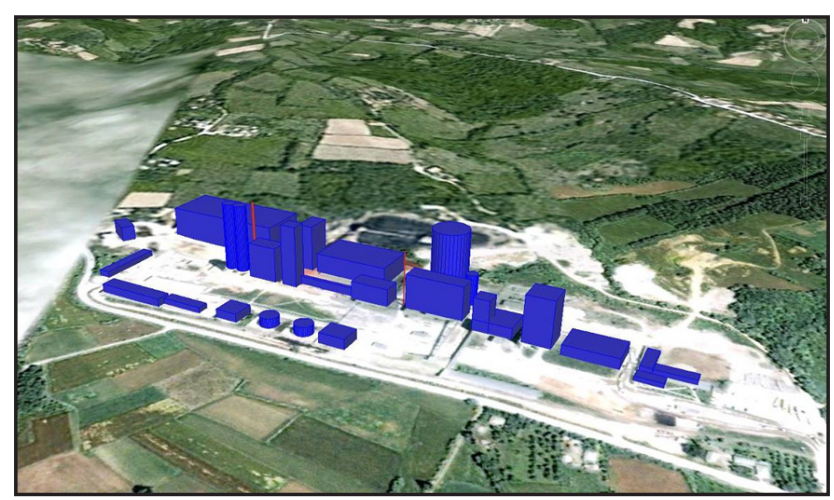

Figure 2: 3D model of cement plant
Taking into account all the results obtained through the dispersion modelling of the pollutants from the SRF co-incineration process in the cement plant, a conclusion can be drawn that the impact on the overall quality of air will be negligible. Results of the air pollution dispersion model show that the concentration of particles in the air in the broader area surrounding the cement plant will remain below the defined maximum allowable values.

Therefore, no cumulative impact of the emission of pollutants on the existing quality of air should be expected. The impact of the Cement Plant from the aspect of emissions into the air will remain at the present level. Health hazards to the exposed population due to this process can be considered negligible. Partial substitution of the main fuel with alternative SRF will not cause the appearance of new types of wastewaters and waste or increase in the quantities of the existing ones. An increase in noise levels due to the transport and delivery of SRF to the location of the Cement Plant will be negligible. The use of alternative fuels will not cause any new effects that could produce, together with the existing impacts of the Cement Plant, any new cumulative effects on the environment.

Althouth it is assessed that additional emissions due to the use of SRF will be extremely limited and will not cause an increase of the present effects on the quality of air in the surrounding of the cemenet plant, the manufacturing process and emissions from the plants will be monitored in the same manner as so far. Given the fact that the use of SRF will not lead to a change in quantities and quality of wastewaters or cause generation of additional quantities of waste, monitoring of the environmental impact defined 
by environmental impacta assessment study includes primarily monitoring of the air quality impact and refers to the emissions of pollutants from the raw mill and rotary kiln emitters and air quality at the measuring points in the wider zone of the cement plant.

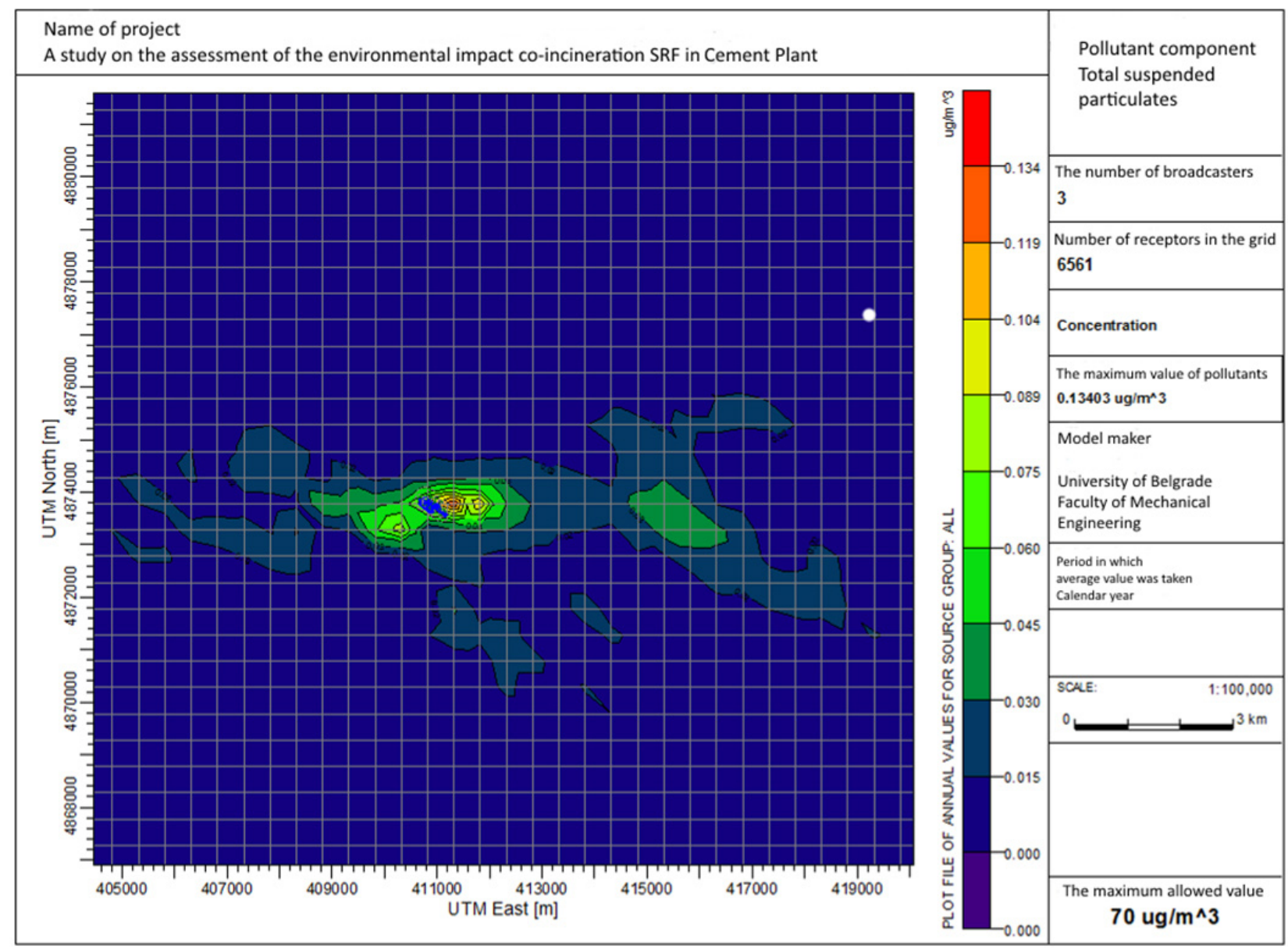

Figure 3: Results of the dispersion modelling of total dust from three main cement plant emitters with the use of SRF

\section{ECONOMIC ASSESSMENT Methodology}

In order to identify the net economic effects of the substitution of the portion of fossil fuels by solid fuel generated from municipal waste, the authors applied the standard approach of comparing the situation "With" Project, that is, if the substitution is made and the situation "Without" Project, that is, if the cement plant continues to use exclusively fossil fuel as a heat energy source in the rotary kiln. The situation "With" Project means that investment (for technical adaptations) is made without production losses and that after project implementation the volume of production will not change in the further exploitation life of the cement plant. "With" Project situation implies an increase of the operating costs (maintenance and insurance of newly-installed equipment and additional consumption of electricity), but also reduction of the heating energy costs due to the substitution of part of more expensive fossil fuel (petroleum coke). "Without" Project situation means unchanged revenues and costs in the planned exploitation life of the cement plant. The criteria for the evaluation of the repair justification are defined according to the standard approach of comparing financial and economic costs and benefits. [04]. For evaluation of the financial cost-effectiveness of the Project the authors used the dynamic approach of the Discounted Cash Flows for "With" and "Without" Project situations. This analysis is meant to show whether the project on partial substitution of main fossil fuels with solid fuels generated from municipal waste increases or reduces the cement plan resources over the entire exploitation period. In order to assess project cost-effectiveness in the overall exploitation period the authors developed a table of "With" and 
"Without" Project financial flows. The "With" Project financial flow gives a dynamic overview of annual revenues from cement sale and transport, on the one side, and the overview of all financial outflows, including investment and operating expenses without depreciation and corporate profit tax, on the other side. The "Without" Project financial flow gives a dynamic overview of annual revenues from cement sale and transport, on the one side, and a dynamic overview of financial outflows excluding depreciation and corporate profit tax. To define the net financial effect of the combined combustion project over the entire economic life it is necessary to establish the difference between the "With" and "Without" Project cash flows. The net difference between these flows represents an annual financial effect of the project on combined combustion of SRF and of the main fossil fuels. The net present value of the Project is a discounted sum of these differences, whereas the internal rate of return (IRR) is an average rate of profitability of the invested funds. The Project's net present value is positive and multiply exceeds the initial investment costs. Discounted value of the net profit at the rate of $5 \%$ is EUR $1,574,296$, which is twice as much as the initial investment. According to this criterion for evaluation of investment justification, the Project is acceptable. Apart from the positive net present value, the Project also achieves a positive internal rate of return of $27.5 \%$. Payback period is 4.5 years, which is acceptable for projects in the cement manufacturing industry. Investment in the project of co-combustion of fossil fuels and municipal waste includes the effects and costs beyond the company which are relevant for the overall social and economic development. As given in the preliminary design, the project of construction of the plants for combined combustion should also have, besides saving of fossil fuels, positive environmental implications. Namely, treatment of portion of municipal waste as a potential heating fuel in the cement industry brings useful environmental effect for the overall economy. Burning plastic, fabrics, cardboard, paper or rubber in the rotary kiln at extremely high temperatures is a preferred option of nonrecyclable municipal waste management. Although purchase or manufacturing of the solid recovered fuel is an economic cost for the investor from the aspect of the overall economy, portion of the municipal waste generated into solid recovered fuel represents an indirect economic benefit. These positive environmental effects are included into the cost-benefit methodological framework and monetarily valued in an indirect way. Based on the assessed local cost of the solid municipal waste treatment at landfills (5-10 euros per ton), costs of the manufacturing SRF from non-recyclable portion of the solid municipal waste (15-20 euros per ton), required quantities of the non-systematised solid municipal waste for manufacturing a ton of SRF ( 3 tons) and annual consumption of SRF $(12,750$ tons per year), the authors calculated the monetary equivalent of positive environmental effect of the project on introducing co-combustion in the cement plant in the amount of EUR 51,000 p.a. (7. 5•3-17.5)・12750. Within the assessment of the economic justification of the project for construction of the co-combustion plant, the authors developed an economic flow, showing all flows of real resources, including investment, operating costs without transfer payments, real savings in the consumption of heating energy, but also positive environmental effect achieved through solid municipal waste management. The economic net present value of the Project is EUR $2,054,443$ and the economic internal rate of return is $33 \%$.

\section{Sensitivity and risk analysis}

Sensitivity analysis is the first phase in the assessment of the investment project risks. Calculating the values of parameters for the project assessment starts with the most likely input values. [3]. Price and quantity of the used SRF, price and quantity of the used petroleum coke, the rate of substitution of petroleum coke with solid recovered fuel produced from waste, price and quantity of electricity, prices of other solid and liquid fuels, value of investment are the parameters that can be changed over the co-combustion implementation and exploitation. Change in the values of these parameters certainly affects the values of relevant parameters for the evaluation of the project justification. Sensitivity analysis is performed by changing one input parameter by certain percentage while keeping other input parameters constant. Therefore, this is a statistical approach that does not include simultaneous changes of input parameters. Selection of critical variables is performed based on the try and error approach. Namely, after an input value is changed by certain percentage, change in the level of evaluation parameters is observed (NPV, 
IRR and payback period of a given investment). The aim of the uncertainty analysis and identifying the most critical items of the project is to find out at which items and by which percentage change of the value of that item the critical (last acceptable) values of outputs can be most rapidly achieved and/or by which percentage certain item should be increased or decreased so that the NPV is zero or IRR is equal to the discount rate. In the sensitivity analysis the percentage change of the value of an input param- eter of the Project which equalizes the net present value to zero and IRR to the discount rate is called the switching value. Table 4 . shows varying of the prices of solid recovered fuels, price of petroleum coke, volume of investment and rate of substitution of petroleum coke with solid recovered fuels. Prices and investment vary in the range $\pm 10 \%$, whereas the rate of substitution of petroleum coke with SRF, except the base case 20:80 is also tested for the case 10:90.

Table 4: Sensitivity Analysis

\begin{tabular}{|c|c|c|c|c|}
\hline Variable & Changes in (\%) & $\mathrm{NPV}(€)$ & IRR (\%) & $\begin{array}{l}\text { Payback } \\
\text { (Years) }\end{array}$ \\
\hline \multirow{3}{*}{ SRF price } & $0 \%$ & 1574296 & 27,5 & 4,36 \\
\hline & $-10 \%$ & 1934406 & $31,9 \%$ & 4,02 \\
\hline & $10 \%$ & 1214185 & $23,0 \%$ & 5,69 \\
\hline \multirow[t]{2}{*}{ Switching values (\%) } & $43,7 \%$ & 0 & $5 \%$ & 1 \\
\hline & Changes in (\%) & $\operatorname{NPV}(€)$ & IRR (\%) & $\begin{array}{l}\text { Payback } \\
\text { (Years) }\end{array}$ \\
\hline \multirow{3}{*}{ Fossil fuels price } & $0 \%$ & 1574296 & 27,5 & 4,36 \\
\hline & $-10 \%$ & 4095070 & $56,6 \%$ & 2,51 \\
\hline & $10 \%$ & -946479 & $-5,9 \%$ & 1 \\
\hline \multirow[t]{2}{*}{ Switching values (\%) } & $6,5 \%$ & 0 & $5 \%$ & 1 \\
\hline & Changes in (\%) & NPV $(€)$ & $\operatorname{IRR}(\%)$ & $\begin{array}{c}\text { Payback } \\
\text { (Years) }\end{array}$ \\
\hline \multirow{3}{*}{ Investment costs } & $0 \%$ & 1574296 & 27,5 & 4,36 \\
\hline & $-10 \%$ & 1652942 & $30,7 \%$ & 4,01 \\
\hline & $10 \%$ & 1495649 & $24,8 \%$ & 5,21 \\
\hline Switching values (\%) & $290 \%$ & 0 & $5 \%$ & 1 \\
\hline $\begin{array}{l}\text { Rate of technical sub- } \\
\text { stitution (SRF:fossil } \\
\text { fuels) }\end{array}$ & $\begin{array}{l}\text { SFR:FF } \\
20: 80 \\
10: 90\end{array}$ & $\begin{array}{l}\text { NPV }(€) \\
1574296 \\
223387\end{array}$ & $\begin{array}{l}\text { IRR (\%) } \\
27,5 \\
8,9 \%\end{array}$ & $\begin{array}{c}\text { Payback } \\
\text { (Years) } \\
4,36 \\
9,81\end{array}$ \\
\hline
\end{tabular}

Sensitivity analysis shows that the Project's most critical input parameter is the price of petroleum coke. If the price of petroleum coke is increased by $6.5 \%$ (from 105 to 112 euros per ton), the project will not earn profit and the payback period of the investment funds exceeds the projected exploitation period of the Project. Co-combustion Project is not particularly sensitive to the change of SRF price. The net present value is zero and the internal rate of return is the discount rate $(5 \%)$ only if the price of solid recovered fuel is increased from EUR 30 to EUR 43 per ton (44\%). Change of the investment costs does not have notable influence over the Project performance. The Project is commercially unjustified only if the investment costs are tripled. Change of the rate of technical substitution of petroleum coke with SRF significantly influences the Project performance. Namely, if the rate of substitution is reduced from 20:80 to 10:90, the discounted net profit of the Project (NPV) falls by $86 \%$ and the average annual profitability (IRR) by $67 \%$. To assess risk of a specific component of the Project, that component must be not only sensitive, but also highly uncertain. Risk assessment is measurement (quantification) of uncertainty. Therefore, for the assessment of the Project's risks, critical components of the Project must be defined. For each critical component of the Project probability of event must be calculated because 
such probabilities also define probability of outputs of the project model analysis. Risk analysis or quantitative assessment of uncertainty thus goes one step beyond the sensitivity analysis by defining weights to the critical variables of the model (price of petroleum coke and SRF), that is, probability at which given value of those variables will occur. Once the distribution of these weights and/or probability for the selected critical variables (based on the sample or otherwise) is determined, it is necessary to define the technique that will reliably transfer the impact of these variables thus (stochastically) determined to the model results. In this case, the term "reliably" means that the occurrence of the critical variable by the selected (determined) distribution of probability is transferred to the result of the model (NPV or IRR). In the risk analysis for the
Project on Co-Combustion of SRF and Petroleum Coke in the cement plant the price of solid recovered fuel was modelled by triangular probability distribution and the price of petroleum coke by log-normal distribution. Figures 4. and 5. give the overview of the obtained results of the NPV and IRR simulation (Latin Hypercube Sampling method).Results of the risk assessment show that the expected value of the internal rate of return (IRR) is $25.49 \%$ with probability of about $25 \%$. Simulation results show that with $90 \%$ probability the internal rate of return of the Co-Combustion Project will range from $1.0 \%$ to $46 \%$. Probability of the negative internal rate is about $10 \%$. With adopted probabilities (by appropriate statistical reliability tests) for the prices of SRF and petroleum coke, the profitability of the Project is significantly above the relevant cost of capital (interest rate).

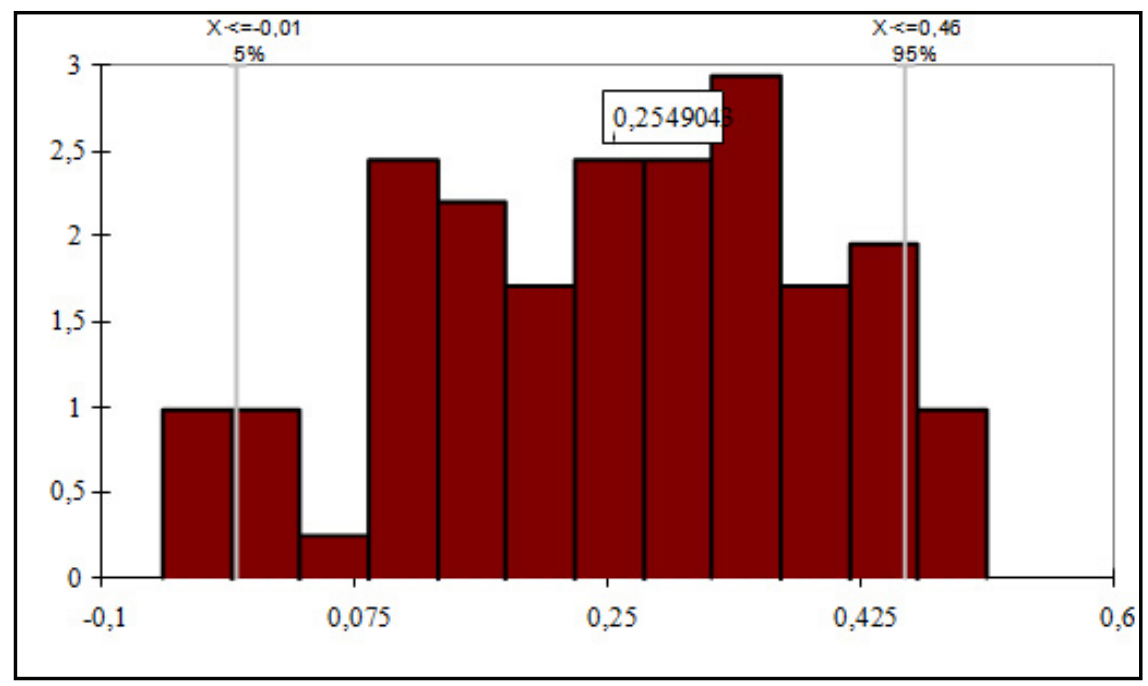

Figure 4. Probability distribution for IRR (\%)

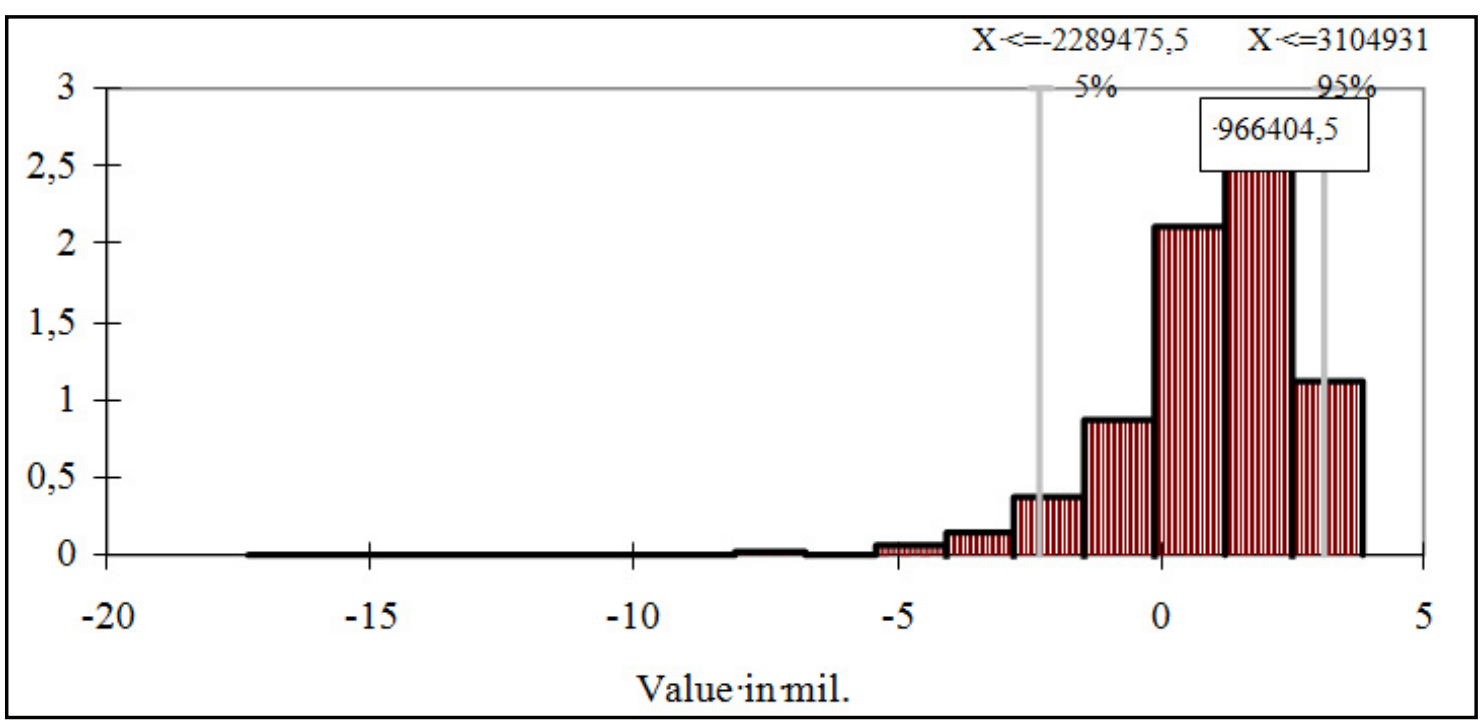

Figure 5: Probability distribution for NPV 


\section{CONCLUSION}

Sensitivity and risk analyses have identified critical input economic parameters and quantified their importance on the performance (results) of the Co-Combustion Project in the Cement Plant. Sensitivity analysis has identified, through a try and error method, the most critical input economic and technical parameters. Minor changes of the price of petroleum coke, price of SRF, volume of investment and the rate of technical substitution of petroleum coke with SRF cause dramatic changes of the Project performance. Given the Terms of Reference, special attention is given to the energy sources. Petroleum coke, that is, the prices of petroleum coke and its combination with SRF, remains the most critical economic parameter. A slight increase in the price of petroleum coke $(6.5 \%)$ brings the Project to the verge of acceptability (total net profit is equal to zero). Given the relatively lower importance of SRF in the overall energy consumption, an increase of the SRF price is not so dramatic from the aspect of the total performance of the Project. In the basic combination of the combined combustion (20:80), the price of SRF needs to go up by $43.7 \%$ for the Project to be at the verge of acceptability. The rate of technical substitution, that is, its change is of crucial importance for the Project performance. If it is assumed that the prices of petroleum coke and SRF are not changed, which is the basic assumption in the sensitivity analysis, a decrease of the substitution rate from 0.25 to 0.11 leads to a dramatic reduction in the net present value and internal rate of return. Namely, if SRF and petroleum coke are technically (energy-based) combined at the rate 10:90, the net present value is still positive, internal rate of return is slightly above the discount rate and the payback period is about 10 years. Given the positive effect size, the volume of investment is a less critical variable. Of course, it does not mean that it is irrelevant how much and when will be spent for the Project implementation, but it gives a possibility for building and purchasing more comfortably and at higher prices the necessary mechanical and electrical equipment. The total price of the Project may even be increased by three times and the investment would be at the verge of justification.

In the probabilistic risk assessment two input parameters were assessed: price of petroleum coke and price of SRF. These are the two variables whose variances affect the Project performance. Although important, the volume of investment and rate of technical substitution of petroleum coke with SRF were not tested through the probability assessment because the investor may directly influence these parameters. Namely, though the volume of investment can also be affected by external factors (change of purchase prices in the course of the construction), it is still a foreseeable parameter and potential uncertainty lasts only in the first two years, until the completion of the construction works and purchase of mechanical and electrical equipment. The risk of the Project was assessed through the probability assessment of the SRF and petroleum coke price variances. With probability of loss (negative net present value) of $20 \%$ and negative internal rate of return of $10 \%$ the Project on the construction of the plants for the use of solid recovered fuel (SRF) for combined combustion with the main fossil fuel can be classified into the group of projects with acceptable (low) level or investment risk.

\section{REFERENCES}

1) Decree on Monitoring Terms and Air Quality Requirements, Official Gazette of the Republic of Serbia, No. 11/2010 and 75/2010)

2) Dondur N. Economic analysis of projects, Faculty of Mechanical Engineering, Belgrade, 2002.

3) EU Guide to cost-benefit analysis of investment projects - European Commission, Directorate General Regional Policy, 2008.

4) Faculty of Mechanical Engineering, University of Belgrade: Use of Solid Recovered Fuel (SRF) in Cement Industry, Project Report, no.502/707/2013. Belgrade, 2013.

5) Fyffe J. R., Breckel A. C., Townsend A. K. and Webber M. E.: Residue-Derived Solid Recovered Fuel for Use in Cement Kilns, July 2012, University of Texas at Austin.

6) Ibbetson C., UK Market Development of Solid Recovered Fuel from MBT Plants, Regen Fuels Ltd, London. UK, 2006.

Paper sent to revision: 21.11.2015.

Paper ready for publication: 15.12.2015. 